Two-sided Institutional Impacts and Informal Entrepreneurship

Motivation in Nigeria

\author{
Abinotam J. Adike \\ $\mathrm{PhD}$ Candidate
}

The Centre for African Entrepreneurship and Leadership (CAEL)/Management Research Centre (MRC), University of Wolverhampton Business School, Nursery Street, City Campus (North), Wolverhampton, WV1 1AD, United Kingdom.

Email: a.adike@,wlv.ac.uk

lucasdyke@yahoo.co.uk Phone: +447449373747

All correspondence should be addressed to the first author (Abinotam J. Adike)

\author{
Paschal U. Anosike \\ Director
}

The Centre for African Entrepreneurship and Leadership (CAEL), University of Wolverhampton Business School, Nursery Street, City Campus (North), Wolverhampton, WV1 1AD, United Kingdom.

Email: p.anosike@wlv.ac.uk Phone: +44 (0) 1902321770

\title{
Yong Wang
}

Reader in family business and entrepreneurship

Entrepreneurship and Small Business Management Research Centre, University of Wolverhampton Business School, Nursery Street, City Campus (North), Wolverhampton, WV1 1AD, United Kingdom.

Email: Yong.wang@,wlv.ac.uk Phone: +44 (0) 1902323964 


\begin{abstract}
Institutions are developed to direct individuals' behaviours in ways that lead to their fulfilment. However, either by deliberate human design or other factors, institutions can also either impact positively or negatively on individuals with entrepreneurial ambition. This characterisation is typical of Nigeria's institutions because of their often two-sided impacts on the individual. This paper uses interview data from a qualitative study to demonstrate how ambiguity, as reflected in the often conflicting effects of institutional arrangements in Nigeria influence the decision to engage in informal entrepreneurship. In particular, the finding that both the enforcement and the absence of enforcement of formal laws potentially cause informality presents a challenge that seriously implicates policy formulation and points to the need for more targeted research.
\end{abstract}

Keywords: informal; institutional voids; labour laws; tax laws; property rights; Nigeria. 


\section{Introduction}

Institutional contexts have been identified as a major determinant of informal economic activity (e.g. Williams, Horodnic, \& Windebank, 2015; Webb, Tihanyi, Ireland \& Sirmon, 2009; Webb, Ireland \& Ketchen, 2014; Friedman, Johnson, Kaufmann \& Zoido-Lobaton, 2000). In Sub-Sahara Africa (SSA), particularly in Nigeria, the institutional context in which business regulations are formed and enacted is characterised by voids, which have a serious negative impact on business activities and outcomes (Dike, 2015; Lewis, 1996, 2006; Meagher, 2013; Ojo, et al., 2014).

Ironically, whereas businesses operating in Nigeria's mainstream formal economy have tended to suffocate under the climate of institutional voids, the informal sector (IS) has flourished under similar conditions (Mairs, et al., 2012; Uzo \& Mairs, 2014). The connection between institutional voids and the persistence of informal economic activity remains under-researched, and therefore presents a significant knowledge gap. This situation points to the need to present a systematic and holistic study that examines the connection between institutional void and informal economic activity.

A major concern here is the underlying institutional factors that give rise to the sector's activities, growth, and persistence. Whereas a number of factors (e.g. overregulation, gender discrimination, rural-urban migration) have been suggested in the literature (De Soto, 1989; Fapohunda, 2012; Todaro, 1969) as potential drivers of informal economic activities, the influence of these factors tend to be contextually defined (Chen, 2007), and thus limits a comprehensive understanding 
of the underlying institutional factors that motivate individuals to enter the IS. In other words, what drives the emergence and growth of informal economic activity tends to differ from one geographical context to another. Ahlstrom \& Bruton (2006, p.302) argued that because 'institutions are typically situation specific; therefore institutional characteristics of a country should be evaluated with regard to a specific phenomenon rather than in terms of general arrangements'.

This article seeks to unravel the interconnections between voids in the institutional context in Nigeria and the growth and persistence of informal economic activities in the country. Thus, the article relies on the understanding provided by the institutional theoretical framework and contemporary IS debate in conceptualising possible relationships in addition to the analysis of interview data. Specifically, it draws from institutional theory literature to examine the role of three specific sources of institutional voids in promoting informal economic activities in the SubSaharan Nigeria context. This marks a fundamental positive shift and contribution toward a more comprehensive analysis of the phenomenon of informal economic activity in Nigeria.

Further to this, the findings in the study would add to the repertoire of IS literature, particularly in Nigeria, and fill the gap in knowledge hitherto lacking as a result of the inability to clearly demonstrate how specific dimensions of institutional voids impact people's decision to engage in informal economic activity thereby promoting the growth of the IS in Nigeria. Researchers, policymakers and other stakeholders, not only in Nigeria, will find this article immensely beneficial as it 
would provide further insight and a more comprehensive frame of reference that would be useful in both research and policy initiatives relating to the IS.

The article consists of five sections. Section one examines the literature on institutional voids and the informal sector. This is followed by a closer look at the IS activity vis-à-vis Nigeria's specific institutional context. The next section explains the methodology of the study. The findings and discussion are presented in the subsequent sections. Drawing from the findings, the paper concludes with implications for future research and policy.

\section{Literature Review}

\section{Institutional voids}

Various studies (e.g., Schrammel, 2013; Lember et al., 2013; Mair \& Marti, 2006, 2009) examined the impact of institutional voids on business activities in different country contexts, especially in developing countries. In conceptualising the notion of institutional voids, Mair and Marti (2006, p. 4) describe the concept as '... situations of absent or weak institutional arrangements that support markets'. Mair and Marti also add that such voids represent opportunity spaces for entrepreneurs. But like Rao et al. (2000, p. 239) who argued that institutional entrepreneurs 'spearhead collective attempts to infuse new beliefs, norms and values into social structures', Mair and Marti noted that voids as opportunity spaces, is reality only for entrepreneurs willing to infuse new beliefs, norms and values into social structures. 
Mair et al. (2012, p. 4), however, observe that although in many cases, institutional voids are viewed as 'empty' of institutions, there is evidence that voids can occur under an abundance of institutions. They attribute this condition to the 'intermediate outcome of conflict and contradiction among local political, community, and religious institutional spheres'. For instance, by their defective processes, the overabundance of institutional arrangements can exclude certain segments within the society from participating in economic opportunities, which then defines the structure of the market in those contexts.

The institutional voids framework is frequently utilised in examining various phenomena in contexts where voids in the institutional framework create loopholes that encourage particular behavioural tendencies. This approach is most appropriate for examining institutional impacts in developing country contexts like Nigeria (Khanna et al., 2005; Mair \& Marti, 2009).

Webb et al. (2013) suggest that certain institutional environments, because of their imperfections, typically create voids and that, the process of filling such voids by entrepreneurs is often informal in nature. From this viewpoint, therefore, informal entrepreneurs perform an important role in an economy. This will however depend on the characteristics of a society's institutional environment. This suggests the need, not only to explain what is meant by institutions in this context but also to profile the institutional context in Nigeria. But first, providing a brief description of the nature of Informal economic activity in Sub-Saharan Africa would be instructive. 


\section{Nature of informal economic activity in Sub-Saharan Africa}

Informal economic activities account for between $8.6 \%$ and $28.3 \%$ of gross domestic product (GDP) in OECD (mature) economies, and up to $59.4 \%$ in SSA (Schneider, 2005). Similarly, $72 \%$ of total nonagricultural employment in SSA is in the IS (Xaba et al., 2002). These statistics demonstrate the significance of the sector to economic activities and the GDP of SSA. Thus, various stakeholders at all levels of government, particularly in SSA, have a renewed interest in the sector, which has been variously interpreted beginning from when Hart (1973) popularised it to the present time. For instance, the World Bank and the International Labour Organisation (ILO) are now partnering with national governments to promote the growth of enterprises and meaningful employment within the IS. This is because of shifting perceptions about the sector as a viable model for dealing with economic and social problems such as unemployment, poverty, and the dwindling fortunes of formal sector employment.

Key among the evidence of such shifting perceptions is the collaborative attempts by various nation-states and major international organisations towards elevating the status of informal entrepreneurs. This has understandably given rise, not only to targeted but also intensive research studies to examine various IS phenomena (e.g., Verick, 2006; Schneider, 2002, 2005; Xaba et al., 2002; Charmes, 2000, 2010; Friedman et al., 2000). But even with the increasingly expanding literature on the IS, establishing a common understanding of key concepts within the IS conceptualisation has remained largely elusive. 
Informality in an economic sense would mean different things in different contexts (Chen, 2007). The term 'informal' when applied in the literal sense of the word in an attempt to describe the nature of informal economic activity, is very limited in scope and can only go as far as providing a literary level of understanding of the phenomenon. However, the IS - both as a sector and a phenomenon - is one that is rather complex. Its complex nature partly derives from the fact that it is contextually defined (Chen, 2007; Grimm et al., 2012).

However, because of the heterogeneous and context-specific nature of informal economic activity (Grimm et al., 2012; Kabra, 1995), there has been lack of a universally agreed-upon definition, leading to inconsistencies and confusion in defining the concept (Bromley, 1978; Peattie, 1987; Ubogu et al., 2011; Krstic \& Sanfey, 2007). Notwithstanding the lack of consensus and the consequent difficulty in providing a precise definition of the IS concept (Henken, 2005), some attempts at defining the concept have been made. One definition of informal economic activity that has featured frequently is that forwarded by Portes et al. These scholars defined the informal economy as the production of legal goods using processes that are not wholly legal (Portes, 1996; Portes \& Haller, 2005; Portes \& Sensenbrenner, 1993).

Webb et al. (2014) approach the definition of informal economic activity from the perspective of institutional theory. According to them, 'the informal economy represents the manifestation of firm and entrepreneurial activity aimed at taking advantage of or filling the void left by the imperfections of the institutional environment' (Webb et al., 2014, p. 7). Although the definitions by Portes et al. and 
that by Webb et al. presented here, use the label 'informal economy' rather than 'informal sector', this later label is more appropriate and is adopted for the purpose of this article. These definitions are nevertheless presented because of certain elements within them that are of critical importance to understanding the nature of informal economic activity.

This article adopts the term informal sector because the article focuses on the enterprise dimension of informality and excludes the employment relationship dimension. Also, the article does not include consideration of the criminal dimensions associated with economic activity in the informal economy.

In SSA, particularly in Nigeria, the IS has generated a lot of debate. In most countries, the IS may only be tolerated or ignored, depending on how the sector is perceived in these countries in terms of its value. The SSA context, as well as other less developed regions of the world such as Asia and Latin America, have particular characteristics that have tended to promote the IS mode of entrepreneurial practice (Spring, 2009). Lavallee \& Roubaud (2009, p. 413) argued:

Operating in the IS is rather the rule than the exception and no recent systemic change may explain this fact. Thus, concepts used to analyse the IS elsewhere are not necessarily applicable to SSA, or at least, their focus may be less relevant in this context.

Ironically, although some have challenged the viability and even the moral value of IS economic activity as an economic model (Gyimah-Brempong \& Kimenyi, 2013; Huitfeldt et al., 2009; Leal-Ordonez, 2013), many however believe that the sector not only provides a means of family subsistence income but also sustainable employment, especially in SSA (e.g., Charmes, 2010; Sparks \& Barnett, 2010; 
Chen, 2007). Chen (2007) has argued that the relevance of the IS stems from the fact that the sector has emerged as a significant socio-economic fabric of many economies in SSA. Lavallee \& Roubaud (2009) on their part posit that in the SSA, the IS has become a major engine for employment, entrepreneurship and growth.

However, the features of the IS in SSA can be better explained and understood by examining a number of variables that share an association with concepts of poverty, employment generation, economic growth, social networks and linkages, population growth and urbanisation, gender-related issues, and technology, training/education and skills (Timberg, 1995).

In Nigeria specifically, the IS has been described as consisting of economic activities in all sectors of the economy that are operated outside the confines of government regulations. More authoritatively, the National Bureau of Statistics (2010), with respect to Nigeria, conceptualised an informal activity as that which operates without binding official regulations (but it may or may not regulate itself internally) as well as one that operates under official regulations that do not compel rendition of official returns about its operations or production process.

Moreover, the definition clearly distinguishes certain informal businesses as those that are not compelled to render returns, although operating under official regulations. The distinction is important as it helps to remove the confusion, which is engendered by other definitions that portray informality broadly as those that are unregulated. Such definitions fail to capture this peculiarity in the Nigerian context 
where a business' official status is viewed in terms of registration or incorporation at the Corporate Affairs Commission (CAC).

Most of the businesses are officially registered and pay tax in one form or another. Yet, because they are not incorporated at the corporate affairs commission, they have limited regulation such as a rendition of returns. Dike (1997, p. 15) describes the conventional criteria for defining informal businesses as 'income-generating activities that are not regulated by, say, minimum wage laws; enterprises are not required to be registered with the appropriate state agencies for tax assessment; standard conditions of work in terms of health and safety regulations are not enforced.' All of the foregoing tends to suggest a strong connection between institutional mechanisms in Nigeria and the economic phenomenon of the IS.

The three major theoretical perspectives of explaining the IS appear to find relevance in the Nigerian context. These are the modernist, legalist and structuralist theoretical perspectives. According to the modernists, the IS is a transient phenomenon that will fizzle out once an economy becomes subsequently modernised or transformed as a feature of capitalist development; it only generates subsistence-level activities and incomes and, is a feature of peripheral economies such as exist in third world countries (see, for example, Lewis, 1954; Rostow, 1959).

From the legalists' perspective, the IS is a popular reaction to over-regulation of the economy by an essentially patrimonial, mercantilist and corrupt state apparatus; it comprises of oppressed extra-legal small entrepreneurs with a sizable amount of 
assets contrary to the modernists' description of the sector (De Soto, 1989). For the structuralists, informality is a creation of the capitalists to exploit cheap informal labour to reduce transaction cost and a constituent of the wider economy rather than simply the result of excess labour or the consequence of over-regulation (Fortuna \& Prates, 1989; Portes \& Schauffler, 1993).

\section{The Institutional Context in Sub-Saharan Nigeria and the Informal Sector}

Broadly, institutions play the role of shaping human activity and, economic activities in particular (Acemoglu et al., 2005; North, 1990). Specifically, Ebben and de Vaal (2011, p. 110) describe the major role of institutions to be that of reducing uncertainty 'by establishing a stable structure for human interaction'. Ebben and de Vaal further argued that institutions 'provide a framework in which transactions and cooperation can occur under conditions that would otherwise make transactions between individuals extremely difficult or even impossible' (de Vaal \& Ebben, 2011, p. 110). This implies that in any business environment where appropriate institutional arrangements are largely absent or even where they exist if they do not have the quality of reducing uncertainty, entrepreneurs are likely to consider alternative solutions.

In any analysis of the impacts of institutional arrangements on economic activity, understanding how business decisions are affected is pertinent. In this context, the overarching question relates to how the effects of the voids created by these institutional arrangements lead to the decision to engage in informal economic activity. It is proposed in this article that the IS provides relief to business people from the negative impacts of the institutional framework in Nigeria.

Thus, faced with the confounding effects of institutional voids such as uncertainty, individuals often choose an informal mode of entrepreneurship rather than operate their business in the formal sector. This proposition is hinged on the widely held belief that Nigeria's institutional framework impacts negatively on business initiatives and outcomes (Lewis, 2006; Osabuohien et al., 2012). Meagher (2007) 
argued that informal institutional arrangements are effectively filling voids that have been created by defective institutional frameworks.

Nigeria, like most SSA countries, fits into the characterisation of the context of institutional voids as provided by Mair et al. (2012). That is, although, there are lots of institutions, the majority of these institutions are ineffective and depict arrays of imperfections thus, creating voids in the general institutional framework. For instance, it is very difficult to do business in Nigeria. This is evident in a recent analysis, which placed Nigeria at 169 out of 189 countries measured in terms of their attractiveness and ease of doing business (World Bank, 2016).

Nigeria's economic profile highlights such negative indices, not for lack of institutions but rather because of the ineffectiveness of the existing institutions. From property rights laws, labour laws, tax administration, to the more localised market institutions, the situation is the same. An associated phenomenon linked to such weakness of institutions is corruption. Indeed, some studies (e.g., Agbiboa, 2013) have argued that corruption mainly contributes to the weak capacity of the state and its institutions.

Analogously speaking, nature does not leave room for vacuums, and institutional arrangements in Nigeria typically exemplify this cliché. In Nigeria, the voids left by the weaknesses in regulating the formal sector institutions seem to have created a condition in which local and traditional institutional arrangements, which are largely informal in nature, flourish. Many writers have made this observation about the institutional context in Nigeria (see, for example, Ostrom, 1993).

In contexts such as Sub-Saharan Africa and in particular Nigeria, where formal institutions are considered to be generally weak, the IS has continued to grow and persist because informal institutional arrangements are filling the voids created by weak formal institutions (Lawrence et al., 2002). Brautigam (1997) in her analysis of the success story of Nnewi industrialists in eastern Nigeria forwards an institutional explanation for their entrepreneurial success. She contends that voids left by both the market and the state were successfully filled by Nnewi industrialists as they used both international linkages and alternative culturally-based networks 
to reduce information uncertainties and principal-agent problems, as well as lower transaction costs (also see Meagher, 2009).

This group of informal entrepreneurs who are mainly in the industrial goods sector operate as large informal firms within clusters. For example, there are informal shoe and garment producers as well as industrial goods suppliers in the south-eastern Nigerian cities of Aba and Nnewi (Anosike \& Ahmed, 2015). Anosike and Ahmed further note that skills among these informal operators is acquired through an informal process of apprenticeship. Corroborating Brautigam's claim, Anosike and Ahmed (2015, p. 558) observed that 'social networks of family and allies are effectively used to enforce contracts and insure risk.'

These analyses of the status of informal institutions vis-à-vis their formal sector counterparts in Nigeria represents a generalised picture of the relative disfunctionality of formal institutions vis-a-vis their informal counterparts. Similarly, analyses provided by Williams et al. (2015), Williams (2014) and Webb et al. (2014) have attempted to show the failure of formal institutional arrangements in regulating and curtailing informal economic activities.

\section{Methodology}

This article is part of a larger qualitative study that investigated the institutional and social factors influencing IS activity in SSA. It was designed as a single case study of Nigeria. As a prelude to the selection of the study participants and the actual collection of data, a pilot study was undertaken to ensure that these processes would lead to the selection of the ideal participants and the collection of quality data. The pilot study helped to identify lapses in both the data collection instrument and the definition of those to be included in the study sample. The result was a more robust data collection instrument and a revised definition of those to be selected for the study — all the stakeholders of the IS in Nigeria. 
The interview protocol consisted of forty questions designed in a semi-structured format. Part A of the interview protocol addressed questions relating to the individual while part B consisted of questions relating to three theoretical frames that underpin the study. Thus, part B was divided into three sections each representing questions on institutions, social exclusion, and personality traits respectively. An important consideration in the design of the interview protocol was the need to understand the IS phenomenon from the subjective meanings derived from participants' experiences and perceptions and the complexities associated with these meanings (Creswell, 2003).

Forty-two participants in five locations spread across four geo-political zones in Nigeria were selected for the study. While snowballing sampling facilitated the recruitment of 150 participants, stratified purposeful sampling was used to select those finally interviewed (see Patton, 1990; Mertens, 2010). In each location, a key informant provided the initial referrals that in turn provided further leads that snowballed into a pool of participants. The most ideal participants were eventually selected through stratified purposeful sampling.

Five cities spread across four geo-political zones in Nigeria were chosen as appropriate locations for data collection. The five cities are Port Harcourt, Yenagoa, Nnewi, Lagos, and Abuja. Data was collected in these five locations between the middle of January and the end of March 2016. In each of the locations, a minimum of five days was initially used to establish acquaintances and the required networking involved in the snowball sampling process. By the second visit, the 
main interviews are done, having identified those that would be finally interviewed. This follows the process of stratified purposeful sampling, which aimed at ensuring that the final sample adequately reflected the heterogeneous nature of the IS.

In all, 38 interviews were finally transcribed manually and fed into version 11 Nvivo qualitative data analysis software. The Nvivo data coding and the process that led to the development of the themes in the study and the subsequent report of findings followed Braun and Clarke's (2006) thematic analysis process.

\section{Findings and Discussion}

A two-sided feature of institutional functioning is reflected in various aspects of Nigeria's institutional framework. Findings relating to three specific dimensions of the institutional framework are focused on in this paper beginning with tax regulation.

\section{Tax regulation}

Tax regulation in Nigeria is among other aspects of the institutional framework that reflects a two-sided feature in the context of analysing the relationship between the institutional context and the incidence of informal economic activity. There is evidence that both the enforcement of tax policies and the absence of its enforcement in Nigeria potentially promote the growth of informal entrepreneurship.

On one side, the perception regarding tax policies/procedures and the enforcement regime is that entrepreneurs generally have a sense of being over-burdened as this 
quote suggests: 'With the present regime, the particular problem that it is giving us is about tax. Yes, the tax they are imposing on companies is too much.' In Nigeria, one issue that has generated much consternation among entrepreneurs is multiple taxes. This often leaves people confused as to what would be the optimal decision. More than one level of government may be requiring payment of the same tax (Nwibo \& Okorie, 2013). In such situations, rather than the different levels of government reconciling such differences and agreeing to only one-level collection of the tax under contention, it is the taxpayers that are often left to sort themselves out. In most cases, they end up paying the tax at the different levels of government (Adebisi \& Gbegi, 2013; Adewusi \& Aluko, 2014; Atawodi \& Ojeka, 2012; Sanni, 2012). These are justifications for the claim of tax burden as this participant affirms: 'See the conflict there, and then you discover that an individual will feel that he is paying double taxation and it can make him to start operating underground and informally.'

Having to spend on taxes more than what would make business sense induces entrepreneurs to consider informal operation as being more optimal since they can in this case more easily evade taxes (Nwibo \& Okorie, 2013). This situation typically describes the context of registered firms that are duly recognised and gazetted for tax purposes. Entrepreneurs often decide to operate otherwise legal businesses clandestinely because they perceive that too much tax burden is placed on them (De Soto, 1989). The literature suggests that business operators, when confronted with ambiguity in institutional arrangements would consider looking for solutions informally (Uzo \& Mair, 2014). This can also be viewed from the perspective that the institutional context could create a situation in which 
entrepreneurs are left with multiple options (De La Chaux \& Haugh, 2015). The enforcement of tax policies in Nigeria and the perceived tax burden that results often makes informal modes of entrepreneurship a preferred option as the interview excerpt below suggests:

Why they remain highly informal is to, will I say, to avoid heavy taxation or, along the line, to ensure that they don't pay some of these things, when it comes to government levies, government taxes and so on, and so forth. And again too, they try as much as possible to hide themselves. Some of them don't even have signposts so that you don't track them.

In some instances (in certain segments of the private sector) in Nigeria, there are no known tax laws that cover them and even where they exist there is little or no enforcement. This can be inferred from the claim by this participant that: 'Year in, year out, many people don't pay tax. They just stay away from them [tax], and then nothing happens to them. ...... it is the influence or what helps them to get away from the formal sector and remain perpetually in the informal sector.' The situation described here approximates as an incentive to operate informally. This represents the other side of the two-sided feature of tax institutions in Nigeria. Lack of tax enforcement in some cases could be the result of what is often referred to as 'negotiated' enforcement. Enforcement could be negotiated in some instances (Bromley, 1978; Webb et al., 2014). Timberg (1995) argues that because of the very small size of microenterprises the regulatory enforcement they attract is often relatively little. Timberg's observation here tends to give credence to the argument presented by one participant. He questions, 'Do you know that small businessman that does not have money in his pocket cannot pay tax and do you expect such person without money to follow the law?' This would be more likely in developing country contexts such as we have in SSA. 
In other instances, the tax authorities or other government agencies do not even recognise or contemplate certain categories of businesses or businesses in certain remote locations. This situation typifies what this participant meant when he said, 'They've not come to us to demand tax unless maybe they don't know that we are existing. I don't know.' In these instances, tax enforcement simply does not exist (Chen, 2007). Therefore, such businesses continue to operate informally. Given the lack of access to financial and other resources, most potential entrepreneurs consider those types of businesses that they can operate relatively freely and without any tax pressure as those that make the most sense. This way, they can leverage money that would otherwise have been spent on tax for their working capital needs. From the entrepreneurs' perspective, it is a rational behaviour towards reducing transaction costs. This reinforces Baumol's (1990) argument that the structure of payoffs in a society is the critical issue rather than entrepreneurs' objectives.

This analysis shows that enforcement of tax policies leading to perceptions of tax burden, as well as the weak or outright absence of enforcement, both influence people to choose informal entrepreneurship. Accordingly, as Chen (2007, p.4) observes 'many owner operators of informal enterprises operate semi-legally or illegally because the regulatory environment is too punitive, too cumbersome or simply non-existent. Also, many informal activities do not generate enough output, employment or income to fall into existing tax brackets.'

Chen's observation supports the legalists' viewpoint and reinforces the argument that over-regulation (including taxation) contributes to driving people into informal 
economic activities, but at the same time suggests that the absence of enforcement also produces the same effect regarding engaging in informal entrepreneurship. ILO (2011) report indicates that poor entrepreneurs are encumbered with a heavy tax burden. This is often the case in developing countries such as Nigeria. But it must be pointed out that enforcement in this case (in Nigeria's context) tends in most cases to take a different form characterised by the impunity of enforcement agents. This has the semblance of conventional enforcement but is, in reality, a make-belief sort of act that is equally, if not more ferociously executed by corrupt enforcement officers.

However, Friedman et al. (2000) indicated that higher tax rates are generally correlated with a lower share of the unofficial economy. This seems opposed to any rational sense of logic considering that even the opposing views to the legalists' argument such as the structuralist viewpoint suggest other reasons why people would choose to engage in economic activities rather than suggest that higher taxes would make informality less attractive. Therefore, other factors may account for this finding. Perceptions of unfairness in the administration of taxes added to the problem of poverty and the inability of the state to provide corresponding support to reflect the reciprocal obligation to taxpayers are common excuses for choosing to undertake informal economic activity by small business owners in Nigeria.

Obafemi (2014) listed proliferation of taxes, high level of illiteracy, lack of adequate enforcement for default, loopholes in the tax laws, inadequate tax education and awareness, incommensurate provision of public service by the government, high tax rates, inequitable distribution of income, and corruption in 
public office, as factors responsible for tax evasion and avoidance. These factors all reflect voids in the tax regulatory framework and are strongly linked to the incidence of informal entrepreneurship.

\section{Labour/Health and safety laws}

Like tax administration in Nigeria where both the pressure of over taxation and the absence of it, in some instances, is seen to force people into informal entrepreneurship, the strict enforcement of labour /health and safety regulations or the lack of it can prompt people to go informal. In Nigeria, the institutional and regulatory framework covering the establishment and protection of workers' rights, protection of the vulnerable workers, enforcement of minimum wage compensation, and provision of decent working conditions among others are weak (Okoronkwo, 2008). Folawewo (2015) observed that 'Rules and regulations emanating from the various Acts and legislations governing the operations within the labour market are usually poorly implemented and most often ineffective.' These views align with those expressed by participants in this study as exemplified by the following interview excerpt:

A lot of such companies argue that they cannot pay the minimum wage, so they pay wages that is far lower than the minimum wage... Another thing is... unionizing... they tactically avoid it and ensure that no union comes up in such organization. So these are some of the ways that these businesses circumvent the rules and regulations of government.

The institutional context in Nigeria generally reflects the personnel management practices in every industry. Hamilton's (2006) depiction of the context of the construction industry in Nigeria further highlights the weakness of the institutional framework and implicitly suggests that employees in these settings are in a 
vulnerable position. Hamilton asserts among other things that the construction industry context is characterised by the pervasiveness of regulations, and complicated analyses; the latter, he argued, is a consequence of the diversity of management practices.

Folawewo (2015) on his part elaborates that, as a reflection of the poor level of implementation of labour regulations, the best in terms of compliance is itself only to a very limited extent. In the private sector segment within the formal sector, the level of compliance is very low. With respect to the IS, Folawewo notes that these laws do not even cover them. Not being covered by the law is what makes these businesses informal in the first place. Similarly, Idubor and Oisamoje (2013) argue that low compliance and lack of enforcement of health and safety rules tend to free companies from any liabilities when employees die, are injured or become ill in the process of, and as a result of performing their duties in those companies. Again, similar arguments have been presented by participants, as this example shows: 'Let us not deceive ourselves, laws to protect workers in this country will not work because of unemployment and many business people don't have money to protect workers.' This situation highlights the extent of dormancy of the role of professional associations in preventing such voids through the institutionalisation of appropriate professional norms.

Most firms now prefer informal employment relations as a means of escaping the usual obligations that are associated with the permanent engagement of employees. This is also only possible because of the lack of enforcement of labour laws. Huitfeldt and Jütting (2009) while suggesting that changes in labour regulations 
and/or their implementation may explain increased levels of informal engagement, also reinforce the structuralists' position that informality is a capitalist strategy to reduce labour cost. In Nigeria, formal firms in these instances tend to prefer the engagement of individuals on an informal basis to distribute their products or provide other services. A typical example is telecommunication firms where the use of such individuals to merchandise recharge cards is prominent.

On the other hand, even the minimal attempt at enforcement of labour laws, especially minimum wage, often result in the loss of jobs as employers rather than accept pay increases would instead terminate the employment of agitating staff. This participant, for instance, makes reference to how this has played out in the public sector in Nigeria: 'Didn't you see what trouble minimum wage caused for states against federal government? For government to have problem to pay minimum wage that make them fight to sack workers, how much more private business.' Often self-employment in the IS becomes the only viable alternative for such individuals whose appointments are terminated. Botero et al. (2004), find evidence in their study that when labour is heavily regulated it leads to higher rates of unemployment. Unemployment, in turn, further skews the employee/employer power relations in favour of employers. Thus, it is common to find situations where even court rulings in favour of injured workers or other breaches of the employment contract are disregarded by firms. This participant's observation tends to encapsulate all these issues:

This problem is everywhere in Nigeria. Even few good people, because, when they want to help worker welfare, the same help is used by other bad people to do corruption, it is not working. That is why everybody [is] wise to work for somebody or for government because as you work,[if] you[get] injure [sic] or die, you are on your own. People can be sacked easily and no problem. 
Ironically, these unethical cost-saving strategies adopted by employers ordinarily would result from changes in labour regulations (such as new minimum wage) but firms would in most cases only successfully circumvent these regulations where there is no strict enforcement. However, strict enforcement could make employers decide to adopt informal employment strategies, thus, scaling up the predominance of informal employment relations. Beyond this, firms could change their status to start operating informally.

From the foregoing, therefore, the institutional context as described above presents an analytical challenge. This is because, in the first place, the perceived weak enforcement of labour regulations in the country (Nigeria) would ideally not provide any rational basis or incentive for entrepreneurs to engage in informality. Such argument is based on the assumption that the burden of regulation and its enforcement drives current and potential entrepreneurs into the IS. But this situation, on the other hand, means that workers, not enjoying the required legal protection, may find the situation uncomfortable enough to consider selfemployment which in most cases would be in the IS. That is, weak enforcement of labour regulation would create room for employers to deemphasise the welfare of their employees, which in turn would lead to high rates of labour turnover. Such exits by employees in some cases would ultimately take them to self-employment in the IS rather than to other wage-employments.

The issues raised here regarding labour laws appear to be quite complex. This is because ideally, regulation of labour ought to ensure better welfare for workers 
which then prevents high labour turnover. The resultant effect is reduced numbers of workers exiting the formal sector to take up self-employment in the IS. On the other hand, it is argued that heavy regulation of labour leads to unemployment. It means that heavy regulation of labour, like weak enforcement of labour laws, would result in more self-employment in the IS. In other words, heavy labour regulation or the lack of regulation/enforcement could potentially increase the number of persons that would opt for informal entrepreneurship.

It, therefore, becomes apparent that other important issues are involved, which require addressing in this context. It seems that the level of regulation, perceptions about the appropriateness and fairness of regulations/enforcement, the circumstances and disposition of the individuals who are being regulated, and the role played by corruption in these contexts of enforcement, are important elements that impact the tendency to circumvent these regulations. Particularly, Williams and Kedir (2016) find that corruption is an efficient strategy linked to analyses of cost/benefit ratios and formal institutional deficiencies. The interaction of these factors, in combination influence an individual's decision to engage in informal economic activities.

\section{Property rights}

Appropriate enforcement of property rights regulation is likely to inhibit the growth of informal economic activities, but only in ideal situations. Conversely, inadequate enforcement of property rights regulation or the outright absence of such regulations would promote the growth of informality. For instance, lack of enforcement of property rights provides individuals with the required leverage to 
organise informal settings and arrangements to facilitate the imitation or pirating of products and other intellectual properties in Nigeria (Anthony \& Chinedu, 2015). This participant also expressed these views: 'Law against piracy and infringement of people's patent right exist.... but how effective is the implementation of these laws. You see somebody will produce something very nice, the next moment another person has translated it and copied it.'

However, because in Nigeria the institutional context is considered not ideal, even in those instances where property rights enforcement is assumed to be encouraged, people are not inspired to formalise their business processes. Entrepreneurs in most cases are unwilling to register their patents and other property rights because of the high costs of doing so and because of perceived ambiguities in these processes as this participant argued:

Although, in some cases, if you are lucky, you will meet a judge who has fear of God, who can protect and enforce your right, but how can you even afford to register? After that, you also think of the cost of a lawyer and all that. Best thing is to just forget about government way [formal approach].

First, we shall consider the more logical connection of low or absence of enforcement of property rights with informality. Lack of property rights enforcement is among other factors De la Chaux and Haugh (2015) describe as legal and political barriers to entrepreneurship in the formal sector. Simply put, with the appropriate framework in place for property rights to be enforced and where the procedures for securing such rights are reasonably cheap and straightforward then there is little incentive for people to remain in the IS. In fact, this has the potential to depopulate the sector. This is how this participant describes what he considers to be the appropriate response to lack of enforcement of one's 
property rights: 'After you went to engage the services of a watch-night or watchman and at long-run, you find out that watchman is not doing anything. It's better that you leave that watchman...if the thief comes, you will fight them on your own.'

The analogy used by the participant above is logical. Entrepreneurs do not usually waste their limited resources on anything that does not provide the desired or expected benefits. The same is true in this context. The general view of the entrepreneurs interviewed in this study is that it makes no business sense wasting one's time to follow formal procedures for securing property rights in the Nigerian context since the lack of enforcement of property rights will only lead to frustration. Again, this participant presents a more explicit argument:

If they cannot restore my right, maybe because the person that is adulterating or trying to infringe my patent or logo, maybe is richer than me, I will just do without them. I will do things my own way. Why will I obey the law when they cannot restore my rights.

The second institutional context relating to property rights, although not logical, nevertheless also influences people to engage in informal entrepreneurship. This is ironic because, in most cases, the same institutional arrangement that supposedly encourages enforcement of property rights, on the other hand, limits people's ability to secure property rights. Also, the costs of enforcing one's rights, where rights are secured, are quite prohibitive. Thus, most entrepreneurs consider informal solutions more ideal for settlement of disputes arising from their business relations as is the case of this participant: 'They will tell you that they don't need ordinary business name. That it is limited liability company registration that they 
need. So, the hurdle you pass to register patent, the money and wahala [problems]is better not to register.'

The inability to secure property rights has been considered as a major reason why entrepreneurs are not able to secure loans from formal financial institutions thus, compelling them to opt for informal solutions. Moreover, as noted by Akirinola (2012, p. 10), 'without legally protected private property rights, entrepreneurs constantly face the risks of confiscation, forced relocation and harassment'. Faced with such risk, small and micro business operators would naturally adopt informal business approaches that would ensure they are not noticed by government enforcement agents in a bid to circumvent laws and regulations.

Another connection between property rights and growth of informal entrepreneurship in Nigeria has a gender undertone as this participant suggests: 'Especially in the North where they have some businesses they will not like women to engage into or own land, and so on and so forth.... tradition, culture, and so on, and so forth, might hinder some businesses from going beyond the informal level.' As pointed out by Stevenson and St Onge (2011), although the Nigerian constitution is explicit in addressing the issue of gender discrimination, such discrimination in allowing women land ownership still persists. This has been attributed to customary laws and practices, especially in rural communities.

Thus, voids resulting from the asymmetry between formal institutional provisions and traditional belief systems prompt the choice of informal modes of business rather than formal businesses (Williams et al., 2015). The evidence that such gender 
discrimination contributes to the growth of IS can be seen in the large proportion of women in the IS in Nigeria relative to men. Indeed, this trend can be recognised in virtually all the countries in SSA (Chen, 2007; Ellis, 1999; Fapohunda, 2012; ILO, 2012; Soetan, 1995). A more direct relationship between property rights and the growth of informal entrepreneurship can be inferred from the following argument presented by Akirinola (2012, p.10):

Ensuring private property rights and legal security not only prepares the ground for formalising the IS. Secured, clearly defined and effectively enforced property rights greatly encourage any economic activity, also in the informal sector, and facilitate the conversion of private assets (dead capital) into productive capital.

An interesting question emerging from the discourse relates to the ironic situation whereby both enforcement and lack of enforcement of property rights potentially prompt people to choose informal modes of entrepreneurship. Given that for both enforcement and lack of enforcement, seemingly genuine reasons are forwarded for the choice of the IS, would this perhaps make it more appropriate for enforcement of property rights to be context-specific? Addressing this question also requires consideration of the fact that not enforcing property rights is only advantageous to those who capitalise on the voids created to pirate the intellectual property of others.

\section{Conclusion}

Overall, the issues that have emerged in this article span the three dimensions of institutions-regulative, normative and cognitive-cultural. IS' link with institutions, and in particular, the regulatory dimension of the institutional framework of a society is considered explicit and logical. In the first place, the conventional mode of defining informal economic activity is generally related to 
the institutional concept. Consequently, any phenomenon relating to informal economic activity can be more appropriately described in terms of how it relates to either formal or informal institutions or both. As an example, observers of the IS argue that the manner in, which formal regulations have been designed is such that does not accommodate or cover the needs and peculiar characteristics of the micro categories of businesses (see Huitfeldt et al., 2009). This is more likely in the SSA context, and by implication, Nigeria.

It seems obvious from the analyses of the three institutional variables above that understanding the role of institutional voids either in promoting or inhibiting the growth of informal economic activities requires a systematic and well-articulated research programme that goes beyond considering individual institutional variables in isolation of the others. A better approach seems to be one that looks at all the relevant institutional variables as a system of variables that are interrelated and whose influence on IS phenomena can only be explained within the context of such interrelationships. Nevertheless, there appears to be a strong indication, that both positive and negative elements in a society's institutional framework can potentially promote informal economic activities.

A major contribution of this article stems from the fact that it is a pioneering effort in examining the relationship between institutional voids and the emergence, growth, and persistence of informal economic activities in the Sub-Saharan Nigerian context. Further, the article has highlighted some key issues which are significant for understanding the connection between voids in Nigeria's institutional arrangements and the IS but which require further research efforts for 
a more holistic understanding. Therefore, the article provides a window for recognising other important and related areas for future research. These areas generally consist of other aspects of the institutional framework in Nigeria not covered in this article but which may also reflect issues that create voids in the overall institutional framework of the country.

In particular, a more comprehensive and in-depth study is required to fully understand the nature of the interrelationship of the different factors underlying the situation whereby both the enforcement and the absence of enforcement potentially cause engagement in informal economic activity. This dilemma further highlights the imperative on the part of the government to ensure that there is synergy between the legislative arm of government and regulatory agencies in the formulation of laws and the enforcement of such laws. A major policy implication of these findings is the understanding that what individuals decide to do with the law (either obey or circumvent them) is largely a function of their perception of how fair the laws are to them. 


\section{Reference}

Acemoglu, D., Johnson, S., \& Robinson, J. A. (2005). Institutions as a fundamental cause of long-run growth. In, P. Aghion, \& S. Durlauf, (Eds), Handbook of economic growth, (pp. 385-472). Elsevier.

Adebisi, J. F., \& Gbegi, D. O. (2013). Effect of multiple taxation on the performance of small and medium scale business enterprises.(A study of West African Ceremics Ajeokuta, Kogi State). Mediterranean Journal of Social Sciences, 4(6), 323 - 334.

Adewusi, S.O., \& Aluko, A.O. (2014). Assessing the role of governance in promoting small scale business in Kogi State: The Kaba/Bunu experience. IOSR Journal of Business Management, 16(11), 86 - 92.

Agbiboa, D. (2013). One step forward, two steps back: The political culture of corruption and cleanups in Nigeria. CEU Political Science Journal, 8(3), 273 - 95.

Ahlstrom, D., \& Bruton, G. D. (2006). Venture capital in emerging economies: Networks and institutional change. Entrepreneurship theory and practice, 30(2), 299-320. 
Akinrinola, O. O. (2012). Informal Economy, Economic Growth and Poverty in Nigeria: A Macro-Economic Analysis. Available at: https://www.hsbremen.de/internet/studium/stg/isvw /conferences/impactonsfrica.

Anosike, P., \& Ahmed, P. (2015). Informal sector employment opportunities in Sub - Saharan Africa: Legitimate or illegal?, In S. Nwankwo, \& K. Ibeh (Eds), The Routledge companion to business in Africa (pp. 554 - 568). London: Routledge.

Anthony, A. T., \& Chinedu, E. S. (2015). Intellectual property rights in Nigeria: A critical examination of the activities of the Nigerian copyright commission. Journal of Law, Policy \& Globalization, 35, 56 - 61.

Atawodi, O. W., \& Ojeka, S. A. (2012). Factors that affect tax compliance among small and medium enterprises (SMEs) in North Central Nigeria. International Journal of Business and Management, 7(12), 87 - 96.

Baumol, W. J. (1990). Entrepreneurship: Productive, unproductive and destructive. Journal of Political Economy, 98(5), 893-921.

Botero, J. C., Djankov, S., Porta, R. L., Lopez-de-Silanes, F., \& Shleifer, A. (2004). The regulation of labor. The Quarterly Journal of Economics, 119(4), 1339-1382.

Braun, V. \& Clarke, V. (2006). Using thematic analysis in psychology. Qualitative research in psychology, 3(2), pp.77-101. 
Brautigam, D. (1997). Substituting for the state: Institutions and industrial development in Eastern Nigeria. World development, 25(7), 1063-1080.

Bromley, R. (1978). Introduction - The urban informal sector: why is it worth discussing? World Development, 6 (9-10), 1033-1039.

Charmes, J. (2000). African women in food processing: a major, but still underestimated sector of their contribution to the national economy. IDRC.

Charmes, J. (2010). Informal employment, social protection and social capital: dimensions of resilience in Sub-Saharan Africa. Background paper for European Report on Development.

Creswell, J.W. (2003) Research design ( $2^{\text {nd }}$ Ed). Thousand Oaks: Sage Publications

Chen, M.A. (2007). Rethinking the informal economy: Linkages with the formal economy and the formal regulatory environment. (DESA Working Papers No. 46). https://www.un.org/esa/desa/papers/2007/wp46_2007.pdf

De La Chaux, M., \& Haugh, H. (2015, January). How institutional voids shape economic opportunities in refugee camps. In Academy of Management Proceedings (Vol. 2015, No. 1, p. 17965). Academy of Management.

De Soto, H. (1989). The other path: The economic answer to terrorism. New York: Harper and Row Publishers. 
De Vaal, A., \& Ebben, W. (2011). Institutions and the relation between corruption and economic growth. Review of Development Economics, 15(1), 108-123.

Dike, E. (1997). Structural adjustment and small-scale industrial entrepreneurs in south-eastern Nigeria. Geneva: United Nations Research Institute for Social Development.

Dike, V. E. (2015). "Why nations fail" to develop: the case of Nigeria. SAGE Open, 5(4), DOI:10.1177/2158244015611714.

Ellis, F. (1999). Rural livelihood diversity in developing countries: Evidence and policy implications. Overseas Development Institute. Natural Resource Perspectives, 40 .

Fapohunda, T. M. (2012). Women and the informal sector in Nigeria: Implications for development. British Journal of Arts and Social Sciences, 4(1), 35-45.

Folawewo, A. O. (2016). Institutions, regulatory framework and labour market outcomes in Nigeria. Journal of Social and Economic Development, 18(1-2), 6784.

Fortuna, J., \& Prates, S. (1989). The articulation of formal and informal sectors in the economy of Bogata, Colombia. In A. Portes, M. Castells \& L. Benton (Eds), 
The informal economy: Studies in Advanced and less developed countries (78-94). Baltimore: John Hopkins Press.

Friedman, E., Johnson, S., Kaufmann, D., \& Zoido-Lobaton, P. (2000). Dodging the grabbing hand: the determinants of unofficial activity in 69 countries. Journal of public economics, 76(3), 459-493.

Grimm, M., Knorringa, P., \& Lay, J. (2012). Constrained gazelles: high potentials in West Africa's informal economy. World Development, 40(7), 1352-1368.

Gyimah-Brempong, K. \& Kimenyi, M.S. (2013) Youth Policy and The Future of African Development. (Africa Growth Initiative, Brookings Institution Working Paper, No. 9). Washington D.C.: Africa Growth Initiative Brookings Institution. Hart, K. (1973). Informal income opportunities and urban employment in Ghana. The journal of modern African studies, 11(1), 61-89.

Hamilton, D. I. (2006). Contract staff management system in the construction industry in Nigeria. Pakistan Economic and Social Review, 1-18.

Hamilton, D. I., \& Gabriel, J. M. O. (2012). Dimensions of fraud in Nigeria quoted firms. American Journal of social and management sciences, 3(3), 112-120.

Henken, T. (2005). Entrepreneurship, informality, and the second economy: Cuba's underground economy in comparative perspective. Cuba in Transition (Association for the Study of the Cuban Economy), 360-75. 
Huitfeldt, H., Jütting, S., \& Jütting, J. (2009) Informality and Informal Employment. Paris: OECD.

Idubor, E. E., \& Oisamoje, M. D. (2013). An exploration of health and safety management issues in Nigeria's effort to industrialize. European Scientific Journal, ESJ, 9(12).

ILO (2011). Making markets work for jobs (ILO World of work report 2011). Geneva: International Labour Organisation.

ILO (2012). Addressing Informality for Rural Development. (ILO Rural Policy Briefs 2012). Geneva: International Labour Organisation.

Kabra, K. N. (1995). The informal sector: A reappraisal. Journal of Contemporary Asia, 25(2), 197-232.

Khanna, T., Palepu,K., \& Sinha, J. (2005). Strategies that fit emerging markets. Harvard Business Review, 83(6), 63-76.

Krstić, G., \& Sanfey, P. (2007). Mobility, poverty and well-being among the informally employed in Bosnia and Herzegovina. Economic Systems, 31(3), 311335.

Lavallée, E., \& Roubaud, F. (2009). Corruption and the informal sector in SubSaharan Africa. Brookings Papers on Economic Activity, 2, 159-239. 
Lawrence, T. B., Hardy, C., \& Phillips, N. (2002). Institutional effects of interorganisational collaboration: The emergence of proto-institutions. Academy of Management Journal, 45, 281-290.

Lember, V., Kattel, R., \& Kalvet, T. (Eds.). (2013). Public procurement, innovation and policy: International perspectives. Springer Science \& Business Media.

Lewis, A. (1968). Reflections on Unlimited Labour. (Development Research Project Discussion Project No. 5) Princeton, New Jersey: Woodrow Wilson School, Princeton University.

Lewis P. (2006). The dysfunctional state of Nigeria. In N. Birdsall, M. Vaishnav, and R. L. Ayres (Eds), Short of the goal: U.S. policy and poorly performing states (pp. 83 - 116). Washington D.C: Centre for Global Development.

Mair, J., \& Marti, I. (2006). Social entrepreneurship research: A source of explanation, prediction, and delight. Journal of world business, 41(1), 36-44.

Mair, J., \& Marti, I. (2009). Entrepreneurship in and around institutional voids: A case study from Bangladesh. Journal of business venturing, 24(5), 419-435.

Mair, J., Marti, I., \& Ventresca, M. (2012). Building inclusive markets in rural Bangladesh: how intermediaries work institutional voids. Academy of Management Journal, 55, 819-850. 
Meagher, K. (2007). Introduction: Special Issues on Informal Institutions and Development in Africa. Afrika Spectrum, 42(3), 405 - 418.

Meagher, K. (2009). The informalisation of belonging: Igbo informal enterprise and national cohesion from below. Africa Development, 34(1), 31 - 46.

Meagher, K. (2013). Unlocking the informal economy: A literature review on linkages between formal and informal economies in developing countries. Work. ePap, 27.

Mertens, D. M. (2010). Transformative mixed methods research. Qualitative inquiry, 16(6), 469-474.

National Bureau of Statistics (2010) Households and Micro Enterprises (Informal Sector. (National Manpower Stock and Employment Generation Survey, 2010). Abuja, Nigeria.

North, D.C. (1990). Institutions, institutional change and economic performance. Cambridge: Cambridge University Press.

Nwibo, S. U., \& Okorie, A. (2013). Constraints to entrepreneurship and investment decisions among agribusiness investors in Southeast, Nigeria. International Journal of Small Business and Entrepreneurship Research, 1(4), 30-42. 
Obafemi, F.A. (2014). An empirical study of tax evasion and tax avoidance: A critical issue in Nigeria economic development. Journal of Economics and Sustainable Development, 5(18), 22 - 26.

Ojo O, P., Friday Aworawo, F., \& Ifedayo, E. (2014). Governance and the challenge of socio-economic development in Nigeria. Journal of Sustainable Development, Law and Policy, 3(1) 132-148.

Okoronkwo, J. O. (2008). Handbook on labour administration in Nigeria: guidelines for labour inspectors and practioners. Abuja: Boremore Associates Nigeria Ltd.

Ordóñez, J. C. L. (2014). Tax collection, the informal sector, and productivity. Review of Economic Dynamics, 17(2), 262-286.

Osabuohien, E., Efobi,U.R. \& Salami, A. (2012). Planning to fail or failing to plan: institutional response to Nigeria's development question. (ADB Working Paper, No. 62). African Development Bank.

Ostrom, V. (1993). Cryptoimperalism, predatory states, and selfgovernance. In V. Ostrom, D. Feeny \& H. Picht (Eds), Rethinking Institutional Analysis and Development (pp. 43 - 68). San-Francisco: ICS Press.

Patton, M.Q. (1990). Qualitative Evaluation and Research Methods (2nd ed.). Newbury Park, California: Sage Publication. 
Peattie, L. (1987). An idea in good currency and how it grew: the informal sector. World development, 15(7), 851-860.

Portes, A., \& Haller, W. (2005). The informal economy. In N. J. Smelser \& R. Swedberg (Eds), The handbook of economic sociology (2nd ed.) (pp. 403-425). Princeton, NJ: Princeton University Press \& Russell Sage Foundation.

Portes, A., \& Schauffler, R. (1993). Competing perspectives on the Latin American informal sector. Population and Development Review, 19 (1), 33-60.

Portes, A., \& Sensenbrenner, J. (1993). Embeddedness and immigration: Notes on the social determinants of economic action. American journal of sociology, 98(6), 1320-1350.

Rao, H., Morrill, C., \& Zald, M. N. (2000). Power plays: How social movements and collective action create new organizational forms. Research in organizational behavior, 22, 237-281.

Rostow, W. W. (1959). The stages of economic growth. The Economic History Review, 12(1), 1-16.

Roxas, H.B., Lindsay, V., Ashill, N., \& Victorio, A. (2006). An institutional view of local entrepreneurial climate. Journal of Asia Entrepreneurship and Sustainability, 3(1), 1-28. 
Sanni, A. (2012). Multiplicity of taxes in Nigeria: Issues, problems and solutions. International Journal of Business and Social Science, 3(17), 229 - 236.

Schneider, F. (2002, July). Size and measurement of the informal economy in 110 countries. In Workshop of Australian National Tax Centre, ANU, Canberra.

Schneider, F. (2005). Shadow economies around the world: what do we really know?. European Journal of Political Economy, 21(3), 598-642.

Schrammel, T. (2013) Bridging the Institutional Void: An Analytical Concept to Develop Valuable Cluster Services", Management Revue. Socio - economic Studies, 24(2), pp.114-132.

Soetan, F. (1995). Technology and women's ventures in nigeria's urban informal sector. In M. O. Osita, B. O. Oyeyinka, \& H. M. Mlawa (Eds), Technology Policy and Practice in Africa, IDRC, 315.

Stevenson, L. \& St-Onge, A. (2011). Assessment of the environment for the development of women's entrepreneurship in Cameroon, Mali, Nigeria, Rwanda and Senegal. Geneva: ILO Publication.

Sparks, D. L., \& Barnett, S. T. (2010). The informal sector in Sub-Saharan Africa: out of the shadows to foster sustainable employment and equity?. The International Business \& Economics Research Journal, 9(5), 1 - 11. 
Spring, A. (2009). African women in the entrepreneurial landscape: Reconsidering the formal and informal sectors. Journal of African Business, 10(1), 11-30.

Timberg, T. (1995). The poor versus the disfranchised: welfare versus empowerment. Economic Development and Cultural Change, 43(3), 651-662.

Todaro, M. P. (1969). A model of labour migration and urban unemployment in less developed countries. The American economic review, 59(1), 138-148.

Tokman, V.E. (2007), “Monernising the Informal sector”, DESA Working Papers Series, No. 42.

Ubogu, A. E., Laah, J. G., Udemezue, C. E., \& Bako, A. R. (2011). Determinants of the locational decisions of informal sector entrepreneurs in urban Zaria. Journal of Geography and Geology, 3(1), 215 - 226.

Uzo, U., \& Mair, J. (2014). Source and patterns of organizational defiance of formal institutions: Insights from Nollywood, the Nigerian movie industry. Strategic Entrepreneurship Journal, 8(1), 56-74.

Verick, S. (2006). The impact of globalization on the informal sector in Africa. Economic and Social Policy Division, United Nations Economic Commission for Africa, 88 . 
Webb, J. W., Bruton, G. D., Tihanyi, L., \& Ireland, R. D. (2013). Research on entrepreneurship in the informal economy: Framing a research agenda. Journal of Business Venturing, 28(5), 598-614.

Webb, J. W., Ireland, R. D., \& Ketchen, D. J. (2014). Toward a greater understanding of entrepreneurship and strategy in the informal economy. Strategic Entrepreneurship Journal, 8(1), 1-15.

Webb, J. W., Tihanyi, L., Ireland, R. D., \& Sirmon, D. G. (2009). You say illegal, I say legitimate: Entrepreneurship in the informal economy. Academy of Management Review, 34(3), 492-510.

Williams, C. C., Horodnic, I. A., \& Windebank, J. (2015). Explaining participation in the informal economy: an institutional incongruence perspective. International Sociology, 30(3), 294-313.

Williams, C. C., \& Kedir, A. M. (2016). The impacts of corruption on firm performance: some lessons from 40 African countries. Journal of Developmental Entrepreneurship, 21(04), 1 - 18.

World Bank (2016) Doing business in 2016: Measuring regulatory quality and efficiency. World Bank Group Flagship Report. Washington, DC: World Bank Group. 
Xaba, J., Horn, P., Motala, S., \& Singh, A. (2002). Informal sctor in Sub-Saharan Africa (No. 993551903402676). International Labour Organization. 